\title{
Standards of consistency of Saudi sports legislation with international legislation
}

\section{Dr. Nayef Hanif Al Qahtani}

The word "law" has been translated into our Arabic language with the Greek root KANUN. It means a straight stick, expressing a kind of fixed system that regulates the behavior and relations of people in society on a compulsory basis. The word legislation means the enactment of laws in a country. The competent public authority in the state and the legislation also refers to the set of legal rules that are developed in this way. The most important feature of the legislation is to put it in written form, in writing. (4: 6)

The legislation is the establishment of legal rules in texts by the legislative authority of the country, whether this power is in the hands of the ruler or a parliamentary body with the head of state. The term of legislation also refers to the same legal basis as the competent authority; this authority includes one or more legal rules. The term is sometimes used in the sense of the source and sometimes in the sense of the legal basis derived from this source, for each rule or legal basis in the form of a competent authority in the state, such as tax legislation and emergency legislation. (5: 19)

The sports movement is witnessing increasing interest in the sport relationship with sports legislation, where the law has become in all fields, economic, political or sports, and some believe that the laws and regulations are not suitable for the sports field and that they are far from sports practice only in the framework of the rules of the games such as football, , But it has become an important and vital issue for sports management and sports practice, but also influential in national production in many developed countries, and the Olympic Charter is the governing of the work of the Olympic movement, so must take it about Develop the legislative policy of the sports movement.

The legitimacy of the sports institutions is provided by setting the goals of the 
sports institution through the general political framework of the state, then the civil laws in general, then the laws of the civil sport organizations, the regulations of the statute of the Olympic Committee, the federations and the sports clubs in particular with the importance of formulating the objectives of each sports body in accordance with its concept and vision Special. (19: 36)

Article 5 of UNESCO's International Charter on Physical Education and Sport states that governments, public authorities, schools and sports bodies at all levels must cooperate and plan together to ensure the optimal use of facilities, equipment and equipment for physical education and sport.

The

UNESCO

International Charter in its article 9 on national systems and its role in physical education and sport states that it is essential that public authorities at all levels and specialized non-governmental bodies promote educational and sports activities whose educational value appears to be more focused and focused on the implementation of projects,
And to take all other measures to encourage, promote and supervise sports activities.

The public authorities must also take the necessary financial measures to encourage such activities. All institutions responsible for physical education and sport must develop a stable, comprehensive and decentralized plan of action in the framework of lifelong learning to allow continuity and coordination between compulsory and other free and automatic activities. (2: 4-5)

There is also a close relationship between law and sports, where the law is the organizer of the sports movement and explains the relationship between individuals, institutions and society. The regulations of each Olympic Committee and all Olympic associations must conform to the provisions of the Olympic Charter and if there is any doubt about the application or interpretation of these regulations To any Olympic committee or if there is a contradiction between its regulations and the provisions of the Olympic Charter, the provisions of the Olympic 
Charter will be taken as the Charter is the basic legislation and all sports organizations linked to each other should not violate the Olympic system and considers it as a fixed entity. (6: 51)

The regulations of each Olympic Committee and all Olympic associations must match the provisions of the Olympic Charter. If there is any doubt about the application or interpretation of these regulations to any Olympic Committee or if there is a conflict between their regulations and the provisions of the Olympic Charter, In the Olympic Charter, where the Charter is the basic legislation and all sports organizations linked to each other not to violate the existing system and considers it a permanent entity.

The Olympic Charter is the Constitution of the Olympic Movement and the organization of the Olympic Games, the body of rules and regulations approved by the International

Olympic

Committee. In the event of a dispute or controversy over the interpretation or application of these decisions, some cases by arbitration before CAS. It is a supreme body independent of the I. O. C (6: 54)

\section{Research problem:}

There is currently a confusion in the definition of sports bodies where there are no clear lines to separate between the bodies working in the framework of professionalism or hobby and how to deal with these bodies professional bodies follow in their laws and regulations international associations responsible for sport and follow the National Olympic Committees IOC and we find that the civil bodies Sports, which work in the framework of hobby and expand the rule of practice depends on the state in decision-making and development of resources, so a new law must be developed that sports organizations civil civil organizations follow the Kingdom of Saudi Arabia, whether working in Ata The investment in the sports field should be included in the laws and regulations in force, especially in light of the sports renaissance that the Kingdom is currently living in, and opening up the investment horizons through the privatization of sports clubs 
and the freedom of these bodies and organizations to develop their own resources and the relationship of local sports organizations with international organizations. , And here lies the problem of research where the local legislation in the Kingdom of Saudi Arabia does not include the existence of a law on sports or regulations that show the separation between professional sports bodies or that work in the framework of the hobby and the purpose of sports bodies and how the existence of mechanisms Ensure clear and keep this in mind the consistency of local sports legislation in line with international sports legislation.

\section{Research goal:}

The research aims to establish criteria for the harmonization of Saudi sports legislation with international legislation through:

1- Recognition of the legislative rights and duties of the Saudi sports bodies.

2- To identify the mechanisms of developing the legislative policy of Saudi sport.

3- Identifying the role of governmental and private sports bodies in formulating proposals for sports legislation.

\section{Search queries}

- What are the legislative rights and duties of the Saudi sports bodies?

- What are the mechanisms for developing the legislative policy of Saudi sport?

- What is the role of government sports bodies and eligibility in the formulation of proposals sports legislation?

\section{Search terms:}

\section{Legal Article:}

A legal provision containing one provision covering a particular aspect of a law, and may contain more than one paragraph, but all of them are related to the same side, and the articles cover all the provisions of the law. $(5: 36)$ Sports Law

A set of legal rules governing the relations of individuals working in the field of sports, administrative player public whether Kat is a written force called legislation or custom. (7: 11)

\section{Related studies:}

\section{A - Arabic Studies:}

1- Eman Al Owaisi: Organizing sport and physical education from the perspective of the Algerian legislation by 
the year 2015 the study aimed at the role of the sports legislation in upgrading the sports organization in the sports and sports school, The study used the descriptive approach and used the questionnaire as a tool for collecting data and sample number (387). ) One of the most important results of the research is that the sports legislation associated with the sports bodies of the civil achievement of the goals at the level of sports in terms of competitive sports, either at the level of sport practice is deficient and the most important recommendations to amend the legislation Sports, especially school sports, which is considered the most important bodies that work to spread the rule of sports practice is the most important and is also a basis for competitive sports, the more practitioners the greater the opportunity to achieve competitions at a higher level.

2- Ahmed Adam Ahmed, Huda Abdul Rahim Amara, studied in 2014 the impact of sport laws and regulations in the development of sport in Sudan. This study aimed to identify the impact of sport laws and regulations in the development of sport in Sudan. The sample consisted of administrators, officials and players in institutions, The researchers used the questionnaire as a tool for data collection. The most important results of the study are that the current sports laws and regulations in Sudan do not work on the development of sports from the point of view of the sample Where is the law of sport and the Regulations for the year 2013 does not keep pace with developments in international law and constitutional changes and governance federal country, and the most important recommendations of the need to develop sports legislation suited to a professional stage experienced by the sport around the world and take advantage of the country's European experiences and try to apply what fits them with the Sudanese sport selected.

\section{B. Foreign Studies:}

1. In 2005, Chateaureyhand conducted a study entitled "New directions for power at the governmental level in the field of sports." The study aimed to identify the 
governmental intervention in the field of sports and the transition to decentralization. The researcher points out that with the policy of government decentralization, societies are the main partners of sports federations. As well as tend to have an entrance in directing the community towards the sports field so that it has the political effect required for them and therefore we find them prefer to put their men who participate in the political trends at the top of this union Sports on the sports federations that feel jealous of their independence and be opposed to the acceptance of such control and indicates the researcher that government intervention is inevitable inescapable and must be dealt with in accordance with the regulations and legislation available. (26)

2- In 1999, Parrish conducted a study entitled "Law and Politics in the European Union" aimed at linking European law and its policy to sport through the theories of unionism of the European Union and the clarification of the competition law of competitors, a process of linking sport with the law of European competition and the regulation of sport and its relation to the international system. The sport of the European Shariah Court and the relation of busman decisions to the European Shariah Court and its decisions, the future of the sports and political laws of the European Union and its relation to the international transformation and the development of global variables Sport glasses (31)

\section{Search procedures:}

1- Research Methodology: The researcher used the descriptive approach to suit the nature of the research.

2. Community and research sample: The research community is represented in the following categories: (Directors of the departments of the General Presidency for Youth Welfare - Members of the Board of Directors of the Saudi Olympic Committee, members of the boards of the Saudi Olympic Sports Federations).

\section{Data collection tools:}

A - Analysis of documents and records: The researcher used the method of document analysis and analysis of laws and regulations of the basic 
system of the various sports bodies to identify what is already in effect, as well as analysis of the content of the International Charter for Physical Education and Sports and also the analysis of the content of the Olympic Charter and identify the most important standards of consistency between local sports legislation Saudi Arabia And international sports legislation.
B- Questionnaire: The researcher designed a questionnaire form. The researcher used the sincerity of the arbitrators and applied the sample to the survey. The researcher used the correlation coefficient between the terms of the interview and the form was presented to the experts and then the questionnaire was applied to the survey sample.

Table (1)

Description of the community and the sample of the research

\begin{tabular}{c|c|l}
\hline \hline $\begin{array}{c}\text { Basic } \\
\text { sample }\end{array}$ & $\begin{array}{c}\text { Survey } \\
\text { sample }\end{array}$ & \multicolumn{1}{|c}{ research community } \\
\hline \hline 11 & 5 & $\begin{array}{l}\text { Directors of departments at the General Presidency of } \\
\text { Youth Welfare }\end{array}$ \\
\hline 6 & 3 & $\begin{array}{l}\text { Members of the Board of Directors of the Saudi } \\
\text { Olympic Committee }\end{array}$ \\
\hline 47 & 12 & $\begin{array}{l}\text { Members of the Boards of Directors of Saudi Olympic } \\
\text { Sports Federations }\end{array}$ \\
\hline 54 & 10 & Members of the Boards of Directors of Saudi Sports Clubs \\
\hline 118 & 30 & Total \\
\hline \hline
\end{tabular}

- Calculation of scientific transactions of the questionnaire:

- Honesty: The researcher calculated honesty through:

A- The judges' truth: The form was presented to a group of experts (10) experts in order to explore their scientific opinion on the suitability of the terms for each axis, as well as the extent of the appropriate balance of estimation, to calculate the degree of their agreement on the phrases. Thus, the researcher verified the validity of the content according to the opinions of the experts. The researcher accepted the agreement percentage $70 \%$ and the final form of the form is represented in the number of three axes 44 words. 
Table (2)

Percentage of the arbitrators' honesty

\begin{tabular}{|c|c|c|c|c|c|}
\hline \multicolumn{2}{|c|}{ The first axis } & \multicolumn{2}{|c|}{ The second axis } & \multicolumn{2}{|c|}{ The third axis } \\
\hline No & $\%$ & No & $\%$ & No & $\%$ \\
\hline 1 & $\%$ & 1 & $\%$. & 1 & $\%$ \\
\hline 2 & $\% 9$. & 2 & $\% \vee$ & 2 & $\% 9$ \\
\hline 3 & $\% 1 \ldots$ & 3 & $\% \wedge$ & 3 & $\% 1 \ldots$ \\
\hline 4 & $\%$ \%. & 4 & $\% 1 \ldots$ & 4 & $\%$ \\
\hline 5 & $\%$ & 5 & $\%$ & 5 & $\%$ \\
\hline 6 & $\% 1 \ldots$ & 6 & $\% 1 \ldots$ & 6 & $\%$ \\
\hline 7 & $\%$ & 7 & $\%$ & 7 & $\%$. \\
\hline 8 & $\%$ \% & 8 & $\% 1 \ldots$ & 8 & $\% 9$. \\
\hline 9 & $\% 1 \ldots$ & 9 & $\%$ & 9 & $\% 1 \ldots$ \\
\hline 10 & $\%$ & 10 & $\% \wedge$. & 10 & $\% 1 \ldots$ \\
\hline 11 & $\%$. & 11 & $\% 9$ & 11 & $\% 1 \ldots$ \\
\hline 12 & $\% \wedge$ & 12 & $\% 1 \ldots$ & 12 & $\%$ \%. \\
\hline 13 & $\%$ & & & 13 & $\%$ \\
\hline 14 & $\% 9$ & & & 14 & $\% 9$ \\
\hline 15 & $\% \wedge$. & & & 15 & $\% 9$ \\
\hline 16 & $\% 1 \ldots$ & & & 16 & $\% \wedge$. \\
\hline
\end{tabular}

B- The credibility of internal consistency: The researcher calculated the validity of internal consistency by calculating the coefficient of correlation (Pearson) between the terms of the questionnaire and the total number of axes of the questionnaire, through the sample survey conducted by (30) individuals from outside the basic sample and within the original community of research, Delete any phrases, as shown in the following table:

Table (3)

Correlation coefficient of expressions

\begin{tabular}{|c|c|c|c|c|c|}
\hline \multicolumn{2}{|c|}{ The first axis } & \multicolumn{2}{|c|}{ The second axis } & \multicolumn{2}{|c|}{ The third axis } \\
\hline No. & $\begin{array}{c}\text { Coefficient of } \\
\text { correlation }\end{array}$ & No. & $\begin{array}{c}\text { Coefficient of } \\
\text { correlation }\end{array}$ & No. & $\begin{array}{c}\text { Coefficient of } \\
\text { correlation }\end{array}$ \\
\hline 1 & $.0 \leqslant 9$ & 1 &. OYK & 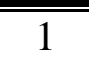 & .091 \\
\hline 2 & .011 & 2 & $\cdot . \leqslant \leqslant$ & 2 & $\cdot \sum V 1$ \\
\hline 3 & .011 & 3 & $.07 \pi$ & 3 & $\because V \vee 1$ \\
\hline
\end{tabular}

Assiut Journal For Sport Science Arts 
Follow Table (3)

Correlation coefficient of expressions

\begin{tabular}{|c|c|c|c|c|c|}
\hline \multicolumn{2}{|c|}{ The first axis } & \multicolumn{2}{|c|}{ The second axis } & \multicolumn{2}{|c|}{ The third axis } \\
\hline No. & $\begin{array}{c}\text { Coefficient of } \\
\text { correlation }\end{array}$ & No. & $\begin{array}{c}\text { Coefficient of } \\
\text { correlation }\end{array}$ & No. & $\begin{array}{l}\text { Coefficient of } \\
\text { correlation }\end{array}$ \\
\hline 4 & $.0 Y r$ & 4 & $.00 Y$ & 4 & $\cdot \varepsilon \cdot r$ \\
\hline 5 & $.7 \leq 1$ & 5 & $.0 \ldots$ & 5 & $\cdot \varepsilon \cdot \varepsilon$ \\
\hline 6 & $.0 . r$ & 6 & .007 & 6 & . rq7 \\
\hline 7 &.$r V V$ & 7 & $. \leqslant 0 \leqslant$ & 7 & .07. \\
\hline 8 & $\because .7 \leqslant Y$ & 8 & $\cdot \wedge 9 \mathrm{~V}$ & 8 & $\cdot . \leqslant 7$ \\
\hline 9 &.$\Sigma V \cdot$ & 9 &.$V V V$ & 9 & .007 \\
\hline 10 &.$\leqslant \vee \cdot$ & 10 &. $.5 \cdot 9$ & 10 & $\because \wedge \cdots$ \\
\hline 11 & $.00 Y$ & 11 & $\cdot . \leqslant 77$ & 11 & $.00 r$ \\
\hline 12 & $.01 \leqslant$ & 12 & $\vee \wedge$. & 12 & .770 \\
\hline 13 & $.7 \leqslant Y$ & & & 13 &.$\vee \vee \wedge$ \\
\hline 14 &.$V 7 V$ & & & 14 & .0 .7 \\
\hline 15 & $.7 \wedge 1$ & & & 15 & $.0 \leq Y$ \\
\hline 16 &.$V \mu r$ & & & 16 & $.0 \leq \pi$ \\
\hline
\end{tabular}

Stability of the questionnaire:

To achieve the stability of the questionnaire, the

Table (4)

researcher used the questionnaire stability process,

Stability coefficient values for the questionnaire

\begin{tabular}{c|l|c}
\hline \hline the Axis & \multicolumn{1}{|c|}{ Axis name } & Alpha. Re \\
\hline \hline the first & $\begin{array}{l}\text { Legislative Rights and Obligations of the } \\
\text { Saudi Sports Authorities }\end{array}$ & 0.909 \\
\hline $\begin{array}{c}\text { The } \\
\text { second }\end{array}$ & $\begin{array}{l}\text { The role of governmental and non- } \\
\text { governmental sports bodies in drafting } \\
\text { proposals }\end{array}$ & 0.837 \\
\hline The third & $\begin{array}{l}\text { Mechanisms for developing the } \\
\text { legislative policy of Saudi sport }\end{array}$ & 0.815 \\
\hline \hline
\end{tabular}

The t value of the t-table at the level of freedom (48) and the level $(0.05)=(0.288)$

Assiut Journal For Sport Science Arts 
It is clear from Table (4) that the values of the coefficients of alpha-stability are between 0.909 and 0.815 , indicating that the questionnaire has an acceptable degree of stability.

Search results, interpretation and discussion

Table (5)

Frequency and percentage of the first axis Legislative Rights and Obligations of the Saudi Sports Authorities (118)

\begin{tabular}{|c|c|c|c|c|c|c|c|c|c|}
\hline \multirow{2}{*}{ No. } & \multirow{2}{*}{ Phrases } & \multirow{2}{*}{$\begin{array}{r}\text { Relative } \\
\text { importance }\end{array}$} & \multirow{2}{*}{ Weighting } & \multicolumn{2}{|r|}{ No } & \multicolumn{2}{|c|}{ To some extent } & \multicolumn{2}{|l|}{ yes } \\
\hline & & & & $\%$ & $\mathrm{Re}$ & $\%$ & $\mathrm{Re}$ & $\%$ & $\operatorname{Re}$ \\
\hline 1 & $\begin{array}{l}\text { The General } \\
\text { Authority for Sport } \\
\text { and the Saudi } \\
\text { Olympic Committee } \\
\text { are working together } \\
\text { to define the general } \\
\text { policy of sports } \\
\text { bodies }\end{array}$ & $97.88 \%$ & 231 & $0.00 \%$ & 0 & $4.24 \%$ & 5 & $95.76 \%$ & 113 \\
\hline 2 & $\begin{array}{l}\text { Local sports } \\
\text { legislation should be } \\
\text { developed in light of } \\
\text { international and } \\
\text { international } \\
\text { legislation }\end{array}$ & $95.76 \%$ & 226 & $0.00 \%$ & 0 & $8.47 \%$ & 10 & $91.53 \%$ & 108 \\
\hline 3 & $\begin{array}{l}\text { The legislative } \\
\text { policy of sporting } \\
\text { bodies is consistent } \\
\text { with the general } \\
\text { policy and laws of } \\
\text { the State }\end{array}$ & $91.95 \%$ & 217 & $0.00 \%$ & 0 & $16.10 \%$ & 19 & $83.90 \%$ & 99 \\
\hline 4 & $\begin{array}{l}\text { Sports federations } \\
\text { formulate proposals } \\
\text { and regulations in } \\
\text { light of the needs of } \\
\text { sports clubs and } \\
\text { raise them to the } \\
\text { Olympic } \\
\text { Committee. }\end{array}$ & $100.00 \%$ & 236 & $0.00 \%$ & 0 & $0.00 \%$ & & $100.00 \%$ & 118 \\
\hline 5 & 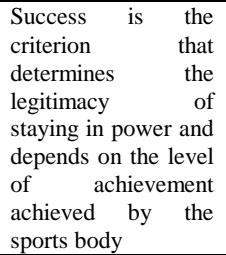 & $75.85 \%$ & 179 & $3.39 \%$ & 4 & $41.53 \%$ & 49 & $55.08 \%$ & 65 \\
\hline 6 & $\begin{array}{l}\text { Sport management } \\
\text { currently conforms } \\
\text { to the internal } \\
\text { policies of the state } \\
\text { and agrees to the } \\
\text { provisions of the } \\
\text { Olympic Charter }\end{array}$ & $97.88 \%$ & 231 & $0.00 \%$ & 0 & $4.24 \%$ & 5 & $95.76 \%$ & 113 \\
\hline
\end{tabular}


Follow Table (5)

Frequency and percentage of the first axis Legislative Rights and Obligations of the Saudi Sports Authorities (118)

\begin{tabular}{|c|c|c|c|c|c|c|c|c|c|}
\hline \multirow{2}{*}{ No. } & \multirow{2}{*}{ Phrases } & \multirow{2}{*}{$\begin{array}{r}\text { Relative } \\
\text { importance }\end{array}$} & \multirow{2}{*}{ Weighting } & \multicolumn{2}{|r|}{ No } & \multicolumn{2}{|c|}{ To some extent } & \multicolumn{2}{|l|}{ yes } \\
\hline & & & & $\%$ & $\operatorname{Re}$ & $\%$ & $\mathrm{Re}$ & $\%$ & $\mathrm{Re}$ \\
\hline 7 & $\begin{array}{l}\text { Relationships and } \\
\text { courtesies affect } \\
\text { the determination } \\
\text { of budgets within } \\
\text { federations and } \\
\text { clubs }\end{array}$ & $30.93 \%$ & 73 & $44.92 \%$ & 53 & $48.31 \%$ & 57 & $6.78 \%$ & 8 \\
\hline 8 & $\begin{array}{l}\text { The } \\
\text { administrative } \\
\text { body has the right } \\
\text { to ratify the } \\
\text { decisions of the } \\
\text { General } \\
\text { Assembly of } \\
\text { sports bodies and } \\
\text { to invalidate any } \\
\text { decision of the } \\
\text { General } \\
\text { Assembly that is } \\
\text { inconsistent with } \\
\text { its policy }\end{array}$ & $21.61 \%$ & 51 & $64.41 \%$ & 76 & $27.97 \%$ & 33 & $7.63 \%$ & 9 \\
\hline 9 & $\begin{array}{l}\text { The } \\
\text { administrative } \\
\text { body has the right } \\
\text { to dissolve the } \\
\text { boards of } \\
\text { directors of } \\
\text { sporting bodies } \\
\text { and the General } \\
\text { Assembly of the } \\
\text { Sports Club if } \\
\text { there are } \\
\text { administrative } \\
\text { irregularities }\end{array}$ & $75.85 \%$ & 179 & $0.85 \%$ & 1 & $46.61 \%$ & 55 & $52.54 \%$ & 62 \\
\hline 10 & $\begin{array}{l}\text { The Boards of } \\
\text { Sport Clubs shall } \\
\text { implement their } \\
\text { decisions for the } \\
\text { benefit of the } \\
\text { Authority and the } \\
\text { members of the } \\
\text { General } \\
\text { Assembly without } \\
\text { waiting for the } \\
\text { approval of the } \\
\text { administrative } \\
\text { body }\end{array}$ & $89.83 \%$ & 212 & $3.39 \%$ & 4 & $13.56 \%$ & 16 & $83.05 \%$ & 98 \\
\hline
\end{tabular}


Follow Table (5)

Frequency and percentage of the first axis Legislative Rights and Obligations of the Saudi Sports Authorities (118)

\begin{tabular}{|c|c|c|c|c|c|c|c|c|c|}
\hline \multirow{2}{*}{ No. } & \multirow{2}{*}{ Phrases } & \multirow{2}{*}{$\begin{array}{l}\text { Relative } \\
\text { importance }\end{array}$} & \multirow{2}{*}{ Weighting } & \multicolumn{2}{|c|}{ No } & \multicolumn{2}{|c|}{ To some extent } & \multicolumn{2}{|c|}{ yes } \\
\hline & & & & $\%$ & $\operatorname{Re}$ & $\%$ & $\mathrm{Re}$ & $\%$ & $\operatorname{Re}$ \\
\hline 11 & $\begin{array}{l}\text { The governmental } \\
\text { body shall establish } \\
\text { with the Olymic } \\
\text { Committee a general } \\
\text { strategy for sport } \\
\text { and identify the } \\
\text { necessary resources } \\
\text { and the institutions } \\
\text { shall be committed } \\
\text { to fulfilling their } \\
\text { roles in coordination } \\
\text { and integration. }\end{array}$ & $95.76 \%$ & 226 & $0.00 \%$ & 0 & $8.47 \%$ & 10 & $91.53 \%$ & 108 \\
\hline 12 & $\begin{array}{l}\text { Sports legislation must } \\
\text { be consistent with what } \\
\text { is stated in the } \\
\text { International Charter } \\
\text { for Physical Education } \\
\text { and the Olympic } \\
\text { Charter and achieve its } \\
\text { objectives through them }\end{array}$ & $91.10 \%$ & 215 & $1.69 \%$ & 2 & $14.41 \%$ & 17 & $83.90 \%$ & 99 \\
\hline 13 & $\begin{array}{l}\text { The General } \\
\text { Authority for Sport } \\
\text { shall determine the } \\
\text { classification of } \\
\text { sports bodies, } \\
\text { whether professional } \\
\text { or amateur, and } \\
\text { establish a scientific } \\
\text { standard for } \\
\text { monitoring the } \\
\text { results of these } \\
\text { bodies }\end{array}$ & $91.10 \%$ & 215 & $0.00 \%$ & 0 & $17.80 \%$ & 21 & $82.20 \%$ & 97 \\
\hline 14 & $\begin{array}{l}\text { The multiplicity } \\
\text { of laws issued by } \\
\text { the administrative } \\
\text { authority affect } \\
\text { the course of } \\
\text { work and } \\
\text { decision making. }\end{array}$ & $97.88 \%$ & 231 & $0.00 \%$ & 0 & $4.24 \%$ & 5 & $95.76 \%$ & 113 \\
\hline 15 & $\begin{array}{l}\text { It is possible to have } \\
\text { a sports law that } \\
\text { checks } \\
\text { constitutionality of } \\
\text { laws in the } \\
\text { administrative field. }\end{array}$ & $93.64 \%$ & 221 & $0.00 \%$ & 0 & $12.71 \%$ & 15 & $87.29 \%$ & 103 \\
\hline 16 & $\begin{array}{l}\text { The importance of } \\
\text { the conformity of } \\
\text { the regulations of } \\
\text { the Olympic } \\
\text { Committee and all } \\
\text { local civil bodies } \\
\text { with the provisions } \\
\text { of the International } \\
\text { Olympic Charter }\end{array}$ & $91.10 \%$ & 215 & $1.69 \%$ & 2 & $14.41 \%$ & 17 & $83.90 \%$ & 99 \\
\hline
\end{tabular}


The researcher believes that most of the responses exceeded the percentage of $75 \%$. This indicates the importance of the first axis of the legislative rights and duties of the Saudi sports bodies where the legislations set by the government authority responsible for sport should be complementary to the Olympic Committee and cooperate in drafting sports legislation. Technical aspect The General Authority for Sport is responsible for administrative and financial affairs. Therefore, cooperation between local governmental and private bodies should be carried out in the development of sports legislation.

The results confirmed that the legislations of sports bodies must conform to the general policy and laws of the state. The sports federations formulate proposals and regulations in the light of the needs of sports clubs and raise them to the Olympic Committee. Success is the criterion that determines the reliance on boards of directors in sports bodies. Achievement achieved by the sports body. The legislator believes that the legislations of the sports body must conform to the general policy of the state and its laws, and that the legislation regulating the sports movement should be flexible and efficient in application. The sports regulations should also take into consideration the needs of sport clubs and sports federations. Issuing legislation after discussion with the Olympic Committee where the Olympic Committee to determine the technical needs of the sports bodies of the civil, so that it can succeed in achieving sports achievements at all levels is where the primary goal The state of the bodies' subsidy and control is to achieve the athletic achievements to raise the flag of Saudi Arabia in the international arena, and if the sports body and the country is currently in need of a rider in sports activity and the General Authority for Sport.

The study also agreed that the sport management is in line with the internal policies of the Queen and is largely compatible with the provisions of the Olympic Charter. However, there are some problems in the sports field, such as relations and courtesies affecting the determination of budgets within the sports federations and clubs. The sports field must be clear and the legislative policy should be written and formulated so as to be clear for all the workers in the field of sport and to set the goal to be achieved and work 
to spread the culture of the Olympic movement and the establishment of scientific rules and standards for the classification of sports bodies The achievement of her sporting achievements at the international level and against which the distribution of subsidies, and this is in line with Ahmed Adam Ahmed study, Huda Abdul Rahim Building 2014.

The study sample indicated that the boards of sports bodies implement their decisions for the benefit of the sports body and members of the general assembly. The Olympic Committee must also participate with the General Authority for Sports in the Kingdom of Saudi Arabia to develop a general strategy for sport and to formulate specific policies and programs in stages. To achieve their roles in coordination and integration, and the establishment of a sector to modernize sport in the General Authority for Sport aims to develop a modern technological policy to help in the adoption of a policy based on scientific development, $\mathrm{C}$ civil and sports bodies to hold negligent, and this is in line with the Owaisi 2015 study.

in the opinion of the researcher, the administrative authority has the right to dissolve the boards of sports clubs in the case of administrative or financial irregularities and send the result of the investigation or irregularities to the responsible authorities in the Kingdom to supplement the results of the investigations. The Olympic Committee is the highest authority for sport management in the Kingdom technically, General of Sport is responsible for the administrative and financial aspects and supervision of management and drainage in sports bodies and this is not contrary to the Olympic Charter, which is the highest sports constitution, and in the development of domestic legislative policy must be taken into account international legislation and most important. There is a need to establish a sector to modernize sport, which includes new departments of professional care as well as management of quality and management of information systems, which is working on developing a modern technological policy that helps to pursue a legislative policy based on scientific development. This is in line with the study of Mohamed Ibrahim Maghawry in 2013. 
Table (6)

Frequency and percentage of the second axis The role of governmental and non-governmental sports bodies in drafting proposals (118)

\begin{tabular}{|c|c|c|c|c|c|c|c|c|c|}
\hline \multirow{2}{*}{ No. } & \multirow{2}{*}{ Phrases } & \multirow{2}{*}{$\begin{array}{r}\text { Relative } \\
\text { importance }\end{array}$} & \multirow{2}{*}{ Weighting } & \multicolumn{2}{|c|}{ No } & \multicolumn{2}{|c|}{ To some extent } & \multicolumn{2}{|c|}{ Yes } \\
\hline & & & & $\%$ & $\mathrm{Re}$ & $\%$ & $\mathrm{Re}$ & $\%$ & $\mathrm{Re}$ \\
\hline 1 & $\begin{array}{l}\text { The legislator has } \\
\text { the right to control } \\
\text { sports laws without } \\
\text { paying attention to } \\
\text { the requirements of } \\
\text { other sports bodies. }\end{array}$ & $23.73 \%$ & 56 & $52.54 \%$ & 62 & $47.46 \%$ & 56 & $0.00 \%$ & 0 \\
\hline 2 & $\begin{array}{lr}\text { Sports } & \text { bodies } \\
\text { contribute r to } \\
\text { drafting legislative } \\
\text { proposals and } \\
\text { submit them to the } \\
\text { Olympic } \\
\text { Committee. } \\
\end{array}$ & $93.64 \%$ & 221 & $0.00 \%$ & 0 & $12.71 \%$ & 15 & $87.29 \%$ & 103 \\
\hline 3 & $\begin{array}{l}\text { The legislative } \\
\text { policy of the } \\
\text { Olympic } \\
\text { Committee is } \\
\text { similar in its } \\
\text { legislation to the } \\
\text { World Olympic } \\
\text { Committees }\end{array}$ & $58.47 \%$ & 138 & $2.54 \%$ & 3 & $77.97 \%$ & 92 & $19.49 \%$ & 23 \\
\hline 4 & $\begin{array}{l}\text { The administrative } \\
\text { body has the right } \\
\text { to intervene in } \\
\text { determining the } \\
\text { regulations } \\
\text { sports bodies. }\end{array}$ & $71.19 \%$ & 168 & $3.39 \%$ & 4 & $50.85 \%$ & 60 & $45.76 \%$ & 54 \\
\hline 5 & $\begin{array}{l}\text { In the event of any } \\
\text { amendment to the } \\
\text { laws, rules and } \\
\text { regulations of the } \\
\text { internal Olympic } \\
\text { Committee must } \\
\text { notify the IOC. }\end{array}$ & $93.64 \%$ & 221 & $0.00 \%$ & 0 & $12.71 \%$ & 15 & $87.29 \%$ & 103 \\
\hline 6 & $\begin{array}{l}\text { To take account of } \\
\text { the international } \\
\text { legislations } \\
\text { governing the } \\
\text { relations of sporting } \\
\text { bodies when } \\
\text { signing any sports } \\
\text { protocol. }\end{array}$ & $99.58 \%$ & 235 & $0.00 \%$ & 0 & $0.85 \%$ & 1 & $99.15 \%$ & 117 \\
\hline 7 & $\begin{array}{l}\text { Government bodies } \\
\text { develop clear and } \\
\text { complementary } \\
\text { legislation for the } \\
\text { Olympic } \\
\text { Committee. }\end{array}$ & $100.00 \%$ & 236 & $0.00 \%$ & 0 & $0.00 \%$ & & $100.00 \%$ & 118 \\
\hline 8 & $\begin{array}{l}\text { There is a declared } \\
\text { policy to improve } \\
\text { the level of } \\
\text { performance of } \\
\text { employees within } \\
\text { sporting bodies. }\end{array}$ & $95.34 \%$ & 225 & $0.00 \%$ & 0 & $9.32 \%$ & 11 & $90.68 \%$ & 107 \\
\hline
\end{tabular}

Assiut Journal For Sport Science Arts 
Follow Table (6)

Frequency and percentage of the second axis The role of governmental and non-governmental sports bodies in drafting proposals (118)

\begin{tabular}{|c|c|c|c|c|c|c|c|c|c|}
\hline \multirow{2}{*}{ No. } & \multirow{2}{*}{ Phrases } & \multirow{2}{*}{$\begin{array}{r}\text { Relative } \\
\text { importance }\end{array}$} & \multirow{2}{*}{ Weighting } & \multicolumn{2}{|c|}{ No } & \multicolumn{2}{|c|}{ To some extent } & \multicolumn{2}{|c|}{ Yes } \\
\hline & & & & $\%$ & $\operatorname{Re}$ & $\%$ & $\mathrm{Re}$ & $\%$ & $\operatorname{Re}$ \\
\hline 9 & $\begin{array}{l}\text { The objectives of } \\
\text { sports bodies are } \\
\text { adaptable according } \\
\text { to the } \\
\text { circumstances and } \\
\text { surrounding } \\
\text { environment. }\end{array}$ & $96.19 \%$ & 227 & $0.00 \%$ & 0 & $7.63 \%$ & 9 & $92.37 \%$ & 109 \\
\hline 10 & $\begin{array}{l}\text { The governmental } \\
\text { body reviews the } \\
\text { internal and external } \\
\text { activities of the } \\
\text { Olympic Committee } \\
\text { and reveews the } \\
\text { international agenda of } \\
\text { sports bodies. }\end{array}$ & $93.22 \%$ & 220 & $0.00 \%$ & 0 & $13.56 \%$ & 16 & $86.44 \%$ & 102 \\
\hline 11 & $\begin{array}{l}\text { There is sometimes } \\
\text { a conflict between } \\
\text { the laws, } \\
\text { regulations and } \\
\text { decisions issued on } \\
\text { the regulation of } \\
\text { sport. }\end{array}$ & $94.07 \%$ & 222 & $0.00 \%$ & 0 & $11.86 \%$ & 14 & $88.14 \%$ & 104 \\
\hline 12 & 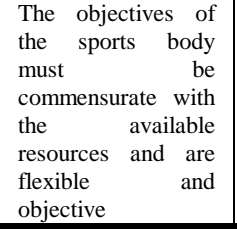 & $97.88 \%$ & 231 & $0.00 \%$ & 0 & $4.24 \%$ & 5 & $95.76 \%$ & 113 \\
\hline $\begin{array}{l}\text { res } \\
\text { res } \\
\text { per } \\
\text { ind } \\
\text { sec } \\
\text { go } \\
\text { eliq } \\
\text { pro } \\
\text { urg } \\
\text { bet } \\
\text { for } \\
\text { Co } \\
\text { adr } \\
\text { fed } \\
\text { anc }\end{array}$ & $\begin{array}{l}\text { in the op } \\
\text { earcher that } \\
\text { onses exc } \\
\text { centage of } 75 \\
\text { icates the imp } \\
\text { ond axis t } \\
\text { ernmental spo } \\
\text { ibility in the } \mathrm{x} \\
\text { posals sports } 1 \\
\text { es the need for } \\
\text { ween the Gen } \\
\text { Sport and } \\
\text { nmittee } \\
\text { hinistrative bo } \\
\text { rations and } \\
\text { identify }\end{array}$ & $\begin{array}{l}\text { inion of } \\
\text { most of } \\
\text { eeeded } \\
5 \% \text {, and } \\
\text { ortance or } \\
\text { he role } \\
\text { rts bodies } \\
\text { ormulatio } \\
\text { egislation } \\
r \text { coordins } \\
\text { eral Auth } \\
\text { the Olyr } \\
\text { and } \\
\text { dy and sp } \\
\text { sports c } \\
\text { ways }\end{array}$ & $\begin{array}{l}\text { the } \\
\text { the } \\
\text { the } \\
\text { this } \\
\text { the } \\
\text { of } \\
\text { and } \\
n \text { of } \\
\text { and } \\
\text { tion } \\
\text { ority } \\
\text { npic } \\
\text { the } \\
\text { orts } \\
\text { lubs } \\
\text { to }\end{array}$ & $\begin{array}{l}\text { The } \\
\text { rese } \\
\text { aca } \\
\text { and } \\
\text { dev } \\
\text { spo } \\
\text { adm } \\
\text { spo } \\
\text { crit } \\
\text { qua } \\
\text { Anc } \\
\text { Spo } \\
\text { mec } \\
\text { plar } \\
\text { ligh } \\
\text { bod }\end{array}$ & $\begin{array}{l}\text { inis } \\
\text { ts b } \\
\text { ria } \\
\text { ifice } \\
\text { the }\end{array}$ & $\begin{array}{l}\text { sults } \\
\text { in } \\
\text { educ } \\
\text { low-up } \\
\text { nents } \\
\text { and m } \\
\text { rative } \\
\text { odies } \\
\text { for } \\
\text { tions } \\
\text { Gener } \\
\text { ay der } \\
\text { term } \\
\text { r spo } \\
\text { heir as }\end{array}$ & $\begin{array}{l}\text { of } \\
\text { the } \\
\text { tion } \\
\text { tec } \\
\text { th } \\
\text { st b } \\
\text { rgans } \\
\text { cord } \\
\text { sele } \\
\text { nd } \\
\text { l Au } \\
\text { lop } \\
\text { ind } \\
\text { ing } \\
\text { istan }\end{array}$ & $\begin{array}{l}\text { scien } \\
\text { field } \\
\text { of sp } \\
\text { anolog } \\
\text { field } \\
\text { sele } \\
\text { opera } \\
\text { ing to } \\
\text { ction } \\
\text { experie } \\
\text { hority } \\
\text { long-te } \\
\text { short-t } \\
\text { bodies } \\
\text { ce to th }\end{array}$ & $\begin{array}{l}\text { ific } \\
\text { of } \\
\text { orts } \\
\text { cal } \\
\text { of } \\
\text { ted } \\
\text { ing } \\
\text { the } \\
\text { of } \\
\text { ace } \\
\text { for } \\
\mathrm{rm} \text {, } \\
\text { in } \\
\text { ese }\end{array}$ \\
\hline
\end{tabular}

communicate with each other, 
In the opinion of the researcher that when the penalties or sanctions of the General Assembly of the Sports Authority must be presented to the Olympic Committee and the General Authority for Sport and must take into account the needs of sports bodies and civil government in the development of sports legislation, and it is necessary to notify the administrative body meetings Board of Directors and make sure that the decisions that To be taken by the institution in violation of the general policy must be attended by a delegate in the General Assembly, and this is consistent with the Chateaureyhand study in 2005. The importance of the participation of the Olympic Committee and sports associations and clubs in the development of draft regulations for each of the bodies in the development of the regulations on sports associations must be the participation of the General Presidency of Sport and the Olympic Committee and sports federations and sports clubs according to their needs and objectives, where sport became a major industry and requires new legislative amendments , And stressed the responses to the need for a declared policy to develop the level of performance of employees within sports bodies, and the need to be the objectives of sports bodies to be adaptable according to the circumstances and the surrounding environment, and the The government must review the plans of the internal and external activities of the Olympic Committee and review the international agenda of the sports bodies, and there is sometimes a conflict between the laws, regulations and decisions issued on the regulation of sports, and must match the objectives of the sports body with the available resources and is flexible and objective, With Parrish's 1999 study

The researcher believes that according to the provisions of the International Charter for Physical Education and Sports, sports management is based on qualified and qualified personnel, so training programs should be developed for the employees of the sports bodies and the need to pay attention to the results of the scientific research and to be prepared in the form of booklets and distributed in the form of quarterly scientific journals on sports bodies. The regulations issued do not act on the speed of decision-making and affect the speed of work, and this is consistent with the study with the study of Iman al-Awaisi 2015. 
Table (7)

Frequency and percentage of the third axis Mechanisms for developing the legislative policy of Saudi sport $\mathbf{n}$ (118)

\begin{tabular}{|c|c|c|c|c|c|c|c|c|c|}
\hline \multirow{2}{*}{ No. } & \multirow{2}{*}{ Phrases } & \multirow{2}{*}{$\begin{array}{c}\text { Relative } \\
\text { importance }\end{array}$} & \multirow{2}{*}{ Weighting } & \multicolumn{2}{|c|}{ No } & \multicolumn{2}{|c|}{ To some extent } & \multicolumn{2}{|c|}{ Yes } \\
\hline & & & & $\%$ & $\mathbf{R e}$ & $\%$ & $\mathbf{R e}$ & $\%$ & $\mathbf{R e}$ \\
\hline 1 & $\begin{array}{l}\text { Sports legislation } \\
\text { should provide } \\
\text { for the freedom } \\
\text { of economic } \\
\text { activity of } \\
\text { sporting bodies }\end{array}$ & $98.73 \%$ & 233 & $0.00 \%$ & 0 & $2.54 \%$ & 3 & $97.46 \%$ & 115 \\
\hline 2 & $\begin{array}{l}\text { Basic legislation } \\
\text { provides for } \\
\text { sports to provide } \\
\text { a free sports } \\
\text { investment } \\
\text { climate }\end{array}$ & $32.20 \%$ & 76 & $44.92 \%$ & 53 & $45.76 \%$ & 54 & $9.32 \%$ & 11 \\
\hline 3 & $\begin{array}{l}\text { Law alone is } \\
\text { sufficient to } \\
\text { bring about } \\
\text { change in sport. }\end{array}$ & $58.90 \%$ & 139 & $2.54 \%$ & 3 & $77.12 \%$ & 91 & $20.34 \%$ & 24 \\
\hline 4 & $\begin{array}{l}\text { The provisions of } \\
\text { the law } \\
\text { (governing the } \\
\text { sports } \\
\text { movement) } \\
\begin{array}{l}\text { currently } \\
\text { establish true } \\
\text { trust } \\
\text { partnership and } \\
\text { between } \\
\text { sports the } \\
\begin{array}{l}\text { community } \\
\text { government }\end{array} \\
\text { agencies }\end{array} \\
\end{array}$ & $97.03 \%$ & 229 & $0.00 \%$ & 0 & $5.93 \%$ & 7 & $94.07 \%$ & 111 \\
\hline 5 & $\begin{array}{l}\text { The } \\
\text { establishment of } \\
\text { sports courts } \\
\text { similar to the } \\
\text { European sports } \\
\text { courts to } \\
\text { consider lawsuits } \\
\text { filed by sports } \\
\text { bodies }\end{array}$ & $22.03 \%$ & 52 & $61.86 \%$ & 73 & $32.20 \%$ & 38 & $5.93 \%$ & 7 \\
\hline 6 & $\begin{array}{l}\text { It is the right of } \\
\text { the General } \\
\text { Authority for } \\
\text { Sport to submit } \\
\text { draft sports laws } \\
\text { without reference } \\
\text { to the Olympic } \\
\text { Committee. }\end{array}$ & $100.00 \%$ & 236 & $0.00 \%$ & 0 & $0.00 \%$ & . & $100.00 \%$ & 118 \\
\hline 7 & $\begin{array}{l}\text { The sports body } \\
\text { must have a legal } \\
\text { personality } \\
\text { similar } \\
\text { international to } \\
\text { sports } \\
\text { organizations }\end{array}$ & $90.25 \%$ & 213 & $0.00 \%$ & 0 & $19.49 \%$ & 23 & $80.51 \%$ & 95 \\
\hline
\end{tabular}


Follow Table (7)

Frequency and percentage of the third axis Mechanisms for developing the legislative policy of Saudi sport n (118)

\begin{tabular}{|c|c|c|c|c|c|c|c|c|c|}
\hline \multirow{2}{*}{ No. } & \multirow{2}{*}{ Phrases } & \multirow{2}{*}{$\begin{array}{c}\text { Relative } \\
\text { importance }\end{array}$} & \multirow{2}{*}{ Weighting } & \multicolumn{2}{|c|}{ No } & \multicolumn{2}{|c|}{ To some extent } & \multicolumn{2}{|c|}{ Yes } \\
\hline & & & & $\%$ & $\mathbf{R e}$ & $\%$ & $\mathbf{R e}$ & $\%$ & $\mathbf{R e}$ \\
\hline 8 & $\begin{array}{l}\text { The } r \text { Sports } \\
\text { Authority has } \\
\text { legal, financial, } \\
\text { tax and immunity } \\
\text { on its premises, } \\
\text { premises, } \\
\text { correspondence } \\
\text { and tools } \\
\end{array}$ & $95.34 \%$ & 225 & $0.00 \%$ & 0 & $9.32 \%$ & 11 & $90.68 \%$ & 107 \\
\hline 9 & $\begin{array}{l}\text { Granting the boards } \\
\text { of directors of } \\
\text { sports organizations } \\
\text { that depend on their } \\
\text { own potential } \\
\text { independence and } \\
\text { freedom to deal } \\
\text { with all matters } \\
\text { without recourse to } \\
\text { the administrative } \\
\text { authority }\end{array}$ & $97.88 \%$ & 231 & $0.00 \%$ & 0 & $4.24 \%$ & 5 & $95.76 \%$ & 113 \\
\hline 10 & $\begin{array}{l}\text { It is necessary to } \\
\text { ensure that the } \\
\text { regulations } \\
\text { governing the } \\
\text { course of work } \\
\text { are applied for } \\
\text { the development } \\
\text { and upgrading of } \\
\text { the technical and } \\
\text { administrative } \\
\text { level, and not } \\
\text { just the } \\
\text { disclosure of } \\
\text { errors and } \\
\text { defects }\end{array}$ & $100.00 \%$ & 236 & $0.00 \%$ & 0 & $0.00 \%$ & & $100.00 \%$ & 118 \\
\hline 11 & $\begin{array}{l}\text { The stability of } \\
\text { the law and the } \\
\text { correct } \\
\text { regulations helps } \\
\text { to achieve } \\
\text { athletic } \\
\text { achievement }\end{array}$ & $61.86 \%$ & 146 & $0.00 \%$ & 0 & $76.27 \%$ & 90 & $23.73 \%$ & 28 \\
\hline 12 & $\begin{array}{l}\text { The General } \\
\text { Commission for } \\
\text { Sport shall } \\
\text { coordinate with } \\
\text { the Olympic } \\
\text { Committee, } \\
\text { sports federations } \\
\text { and sports clubs } \\
\text { and determine } \\
\text { the means of } \\
\text { communication } \\
\text { with each other. }\end{array}$ & $95.34 \%$ & 225 & $0.00 \%$ & 0 & $9.32 \%$ & 11 & $90.68 \%$ & 107 \\
\hline
\end{tabular}


Follow Table (7)

Frequency and percentage of the third axis Mechanisms for developing the legislative policy of Saudi sport $\mathbf{n}$ (118)

\begin{tabular}{|c|c|c|c|c|c|c|c|c|c|}
\hline \multirow{2}{*}{ No. } & \multirow{2}{*}{ Phrases } & \multirow{2}{*}{$\begin{array}{c}\text { Relative } \\
\text { importance }\end{array}$} & \multirow{2}{*}{ Weighting } & \multicolumn{2}{|c|}{ No } & \multicolumn{2}{|c|}{ To some extent } & \multicolumn{2}{|c|}{ Yes } \\
\hline & & & & $\%$ & $\operatorname{Re}$ & $\%$ & $\mathbf{R e}$ & $\%$ & $\mathbf{R e}$ \\
\hline 13 & $\begin{array}{l}\text { Selection of } \\
\text { administrative } \\
\text { bodies } \\
\text { operating in } \\
\text { sports bodies } \\
\text { according to } \\
\text { the selection } \\
\text { criteria for } \\
\text { appropriate } \\
\text { qualifications } \\
\text { and experience } \\
\text { in the sports } \\
\text { field }\end{array}$ & $87.71 \%$ & 207 & $0.00 \%$ & 0 & $24.58 \%$ & 29 & $75.42 \%$ & 89 \\
\hline 14 & $\begin{array}{l}\text { The General } \\
\text { Authority for } \\
\text { Sport sets out } \\
\text { long-term, } \\
\text { medium-term } \\
\text { and short-term } \\
\text { plans for sports } \\
\text { bodies in light } \\
\text { of their } \\
\text { assistance to } \\
\text { these bodies. }\end{array}$ & $97.46 \%$ & 230 & $0.00 \%$ & 0 & $5.08 \%$ & 6 & $94.92 \%$ & 112 \\
\hline 15 & $\begin{array}{l}\text { When planning } \\
\text { the various } \\
\text { programs of } \\
\text { sports bodies, } \\
\text { it is necessary } \\
\text { to take into } \\
\text { consideration } \\
\text { scientific } \\
\text { studies in the } \\
\text { field of sports } \\
\text { management } \\
\text { and training. }\end{array}$ & $14.41 \%$ & 34 & $73.73 \%$ & 87 & $23.73 \%$ & 28 & $2.54 \%$ & 3 \\
\hline 16 & $\begin{array}{l}\text { Impeding the } \\
\text { activity of the } \\
\text { Olympic } \\
\text { Committee, the } \\
\text { federations and } \\
\text { clubs due to } \\
\text { the change and } \\
\text { instability of } \\
\text { national } \\
\text { regulations is } \\
\text { in force. }\end{array}$ & $98.73 \%$ & 233 & $0.00 \%$ & 0 & $2.54 \%$ & 3 & $97.46 \%$ & 115 \\
\hline
\end{tabular}


The researcher believes that most of the responses exceeded the percentage of $75 \%$. This indicates the importance of the third axis mechanisms to develop the legislative policy of Saudi sport. The sample of the research confirmed the stability of the law and the correct regulations helps to achieve the athletic achievement. The General Authority for Sports has the right to submit draft sports laws, Courts of sports similar to European sports courts to consider claims by sports bodies.

The sample responses indicate that the law is not the only one capable of bringing about change in sport, but rather it is an integrated system. The regulations currently support the process of trust between civil and governmental bodies. Which should be properly adapted to the nature of sports bodies and their goals and to issue regulations according to urgent or necessary needs has not changed, and this is consistent with the study of Ahmed Adam
Ahmed, Huda Abdul Rahim Amara study 2014.

The researcher also believes that there is a need to separate the judicial authority from the administrative body, and that the judicial authority becomes separate, whether by establishing a sports arbitral tribunal or establishing a sports court. It is also necessary for the sports organization to have a legal personality. And raise the level of technical and administrative and not just the disclosure of errors and defects only, and grant the governing bodies of sports organizations that rely on their own potential independence and freedom to deal with all matters within the laws of Saudi Arabia, and that the development and modernization of laws and vice versa Update control operations until the goal is the development and upgrading of the technical and administrative level rather than detection of errors and defects only, must allow sports legislation freedom to exploit and invest own resources for sports bodies, and this is in line 
with study Mohamed Ibrahim Maghawry 2013.

The researcher believes that the bodies that depend on their own resources do not need this huge amount of laws, regulations and instructions to manage their institutions and if they do not depend on any subsidies from the Kingdom, but achieve surplus in their budgets have not been controlled and the methods of exchange is through the internal regulations get a return Financial and athletic achievement so it is possible to amend the internal regulations only if they are inconsistent with the law through the General Authority for Sport and the Saudi Olympic Committee, and the need to be integrated between the General Authority for Sport and the Saudi Olympic Committee and sports federations and clubs The framework of local legislation and international legislation for the freedom of economic activity, which has become the curriculum adopted by the Kingdom of Saudi Arabia and became the direction of the Kingdom to invest in the field of sports to obtain added value from Saudi sport.

\section{Conclusions:}

It is clear from the results of the research that the sports legislation and the organization of the sports movement are formulated in a legal manner in accordance with the characteristics and elements of ordinary legislation in all its stages and characteristics. The international legislations should be observed in the forefront of the International Olympic Charter. If all sports are subject to the implementation of its law adopted by all international federations, international legislative policies must be taken into account in the development of the legislative policy of the civil bodies, including clubs Riyadh

Moreover, many amendments and deletions and the addition of the various regulations of the basic system of the sports bodies work on the existence of conflicts and 
overlapping in the competencies and responsibilities which affect the sports movement in general. Therefore, the laws and regulations in the sports field in the Kingdom are not constantly changed in order to achieve this principle.

The results of the research show that there is no court of sports similar to the European sports courts to consider the cases submitted by the sports bodies to consider the differences in the field of conflict for the sports bodies, the existence of the systems to update the activity of the civil bodies and determine the administrative, technical and organizational relationship between the government apparatus and these bodies more clearly. The leaders of civil society organizations should be involved in discussing legislation, laws and regulations before issuing them and participating in setting the rules of international representation at various levels, in partnership with the Olympic Committee, sports federations and clubs. And the importance of developing a long-term strategic plan for Saudi sport in cooperation with the Saudi Olympic Committee, and the lack of interest in developing training courses for sports personnel in all governmental or nongovernmental sports bodies in Saudi Arabia.

\section{Recommendations.}

1 - The need to pay attention to sport as an educational and investment field where sport has become the most important areas for human development and industry and investment at the present time

2- The establishment of the Committee on Sport Law within the committees of the General Authority for Sport and has among its functions the issuance of sports legislation and includes jurists in the sports legislation.

3- The necessity of putting the General Authority for Sport classification of sports bodies, whether professional or amateur and the development of a scientific measure to 
control the results of these bodies

4- Criteria for the selection of individuals to the Department for the success of any work must be in accordance with the technical representation of their administrative, technical and scientific expertise

5- The need to hold courses for the refinement and training of workers and the General Authority for Sport and the Olympic Committee on the latest administrative systems scientific and legislative in the field of sports

6- the need to make an assessment of sports sports bodies at the end of each season and make use of reports on the results of the calendar in the amendment plans of other sports bodies.

7. To grant to the boards of directors of sports organizations that rely on their capabilities for independence and freedom of dealing and to establish for themselves financial, administrative and administrative regulations without relying on the governmental body but in line with the policy of the Kingdom of Saudi Arabia

8- Part of the budget of the General Authority for Sport is allocated to the Olympic Committee to strengthen international relations between the local sports bodies of the various international sports bodies and transfer their expertise

9. Establishment of a sports arbitral tribunal or the establishment of a sports court similar to that of the European courts to hear cases submitted by sports bodies

10- Establishment of a sector for the modernization and development of sport according to the global rules and regulations within the organizational structure of the General Authority for Sport Scientific references:

1- Ahmed Adam Ahmed, Hoda Abdel Rahim Omara: The Effect of Sport Laws and Legislations in Developing Sport in Sudan, published scientific research, Faculty of Physical Education and Sports, Sudan University of Science and Technology, 2014. 
2- International Charter of Physical Education and Sport: International Charter for Physical Education and Sport, United Nations, UNESCO, 1978

3- Eman Al Owais: Organization of Sport and Physical Education from the Perspective of Algerian Legislation, published scientific research, Journal of Science and Techniques of Physical Activity No. 9, Institute of Physical Education and Education, University of Algiers, 2015

\section{4-Bahaa Sayed Mahmoud} and others: Modern trends for the manufacture of sports legislation, Modern Book Center for Publishing and Printing, Cairo, 2016.

5-Saad Jabr: The Introduction to the Study of Law, Dar AlNahda Al-Arabiya, Cairo, 1992 6-Kamal Darwish and Others: Mathematical Systems and the Legislative Structure, The Anglo Library, Cairo, 2012.

7-Hassan Ahmed El Shafei:

Legislation in Physical Education and Sports, Dar El Wafa, Alexandria, 2004

8-Mohamed Ibrahim

Maghawry: Evaluation of sports legislation between hobby and professionalism in the framework of quality, unpublished doctoral thesis, Faculty of Physical Education for Boys, Helwan University, 2013

\section{Second: Foreign Studies:}

9- Chateaureynaud, y. : Sport

- new stkesot power at the local level, Journal des Sciens et techniques des activities physiques et sportive, Vol.10, No.20, Grenoble, France , 2005 10-Parrish: Sports law and policy in the European Union. 1999. 